\title{
Slower ozone production in Houston, Texas following emission reductions: evidence from Texas Air Quality Studies in 2000 and 2006
}

\author{
W. Zhou ${ }^{1}$, D. S. Cohan ${ }^{1}$, and B. H. Henderson ${ }^{2}$ \\ ${ }^{1}$ Department of Civil and Environmental Engineering, Rice University, Houston, Texas, USA \\ ${ }^{2}$ Environmental Engineering Sciences, University of Florida, Gainesville, Florida, 32611, USA \\ Correspondence to: D. S. Cohan (cohan@ rice.edu)
}

Received: 13 June 2013 - Published in Atmos. Chem. Phys. Discuss.: 18 July 2013

Revised: 31 January 2014 - Accepted: 31 January 2014 - Published: 18 March 2014

\begin{abstract}
Airborne measurements from two Texas Air Quality Study (TexAQS) field campaigns have been used to investigate changes of ozone production in Houston, Texas, from 2000 to 2006, a period of major emission reduction measures for petrochemical and other sources. Simultaneous declines in nitrogen oxides $\left(\mathrm{NO}_{\mathrm{x}}=\mathrm{NO}+\mathrm{NO}_{2}\right)$ and highly reactive volatile organic compounds (HRVOCs) were observed between the two periods. We simulate $\mathrm{HO}_{\mathrm{x}}\left(\mathrm{OH}\right.$ and $\left.\mathrm{HO}_{2}\right)$ and organic radicals with a box model, the Dynamically Simple Model of Atmospheric Chemical Complexity, constrained by available airborne observations. Parameters such as total radical production, total $\mathrm{OH}$ reactivity of VOCs and ozone production rate (OPR) are computed to characterize the change of ozone production between 2000 and 2006 in the Houston area. The reduction in HRVOCs led to a decline in total radical production by $20-50 \%$. Ozone production rates in the Houston area declined by $40-50 \%$ from 2000 to 2006, to which the reduction in $\mathrm{NO}_{\mathrm{x}}$ and HRVOCs made large contributions. Despite the significant decline in OPR, ozone production efficiency held steady, and VOC-sensitive conditions dominated during times of most rapid ozone formation, while the slow ozone formation continued to be $\mathrm{NO}_{\mathrm{x}}$-limited. Our results highlight the importance of a balanced approach of ongoing HRVOC controls with $\mathrm{NO}_{\mathrm{x}}$ controls to further reduce $\mathrm{O}_{3}$ levels in the Houston area.
\end{abstract}

\section{Introduction}

The Houston metropolitan area has a long history of nonattainment of the US National Ambient Air Quality Standards for ozone $\left(\mathrm{O}_{3}\right)$, despite substantial emission reduction efforts since the 1970s (Cowling et al., 2007). Houston ozone events usually occur in spring (April-May) and late summer (August-October) in a bimodal nature. Springtime ozone exceedences tend to occur under post-frontal passage meteorological conditions, while the summertime events often feature continuous high temperature and stagnant meteorology over southeast Texas (Haman et al., 2012; TCEQ, 2007). Favored by these meteorological conditions, large amounts of co-emitted $\mathrm{NO}_{\mathrm{x}}$ and VOC from petrochemical facilities in the Houston Ship Channel (HSC) and the nearby urban center lead to high $\mathrm{O}_{3}$ levels (Fig. 1) (Cowling et al., 2007; Parrish et al., 2009; Ryerson et al., 2003).

Unlike the mobile-dominated hydrocarbon emission compositions in many other metropolitan areas in the US, Houston emissions feature highly reactive VOCs (HRVOC), such as $\mathrm{C}_{2} \mathrm{H}_{4}$ and $\mathrm{C}_{3} \mathrm{H}_{6}$, especially in the $\mathrm{HSC}$ region (Kim et al., 2011; Ryerson et al., 2003; Washenfelder et al., 2010). HRVOC emissions result from flaring, fugitive emissions, cooling towers, storage/transport, plastics production, and ethylene and propylene production at petrochemical facilities (Kim et al., 2011). Emission inventories for HRVOC are known to be highly uncertain (Kim et al., 2011). Previous studies have concluded that emission inventories in the HSC underestimated HRVOC emissions by at least one order of magnitude (Cowling et al., 2007; Parrish et al., 2009; Ryerson et al., 2003). 


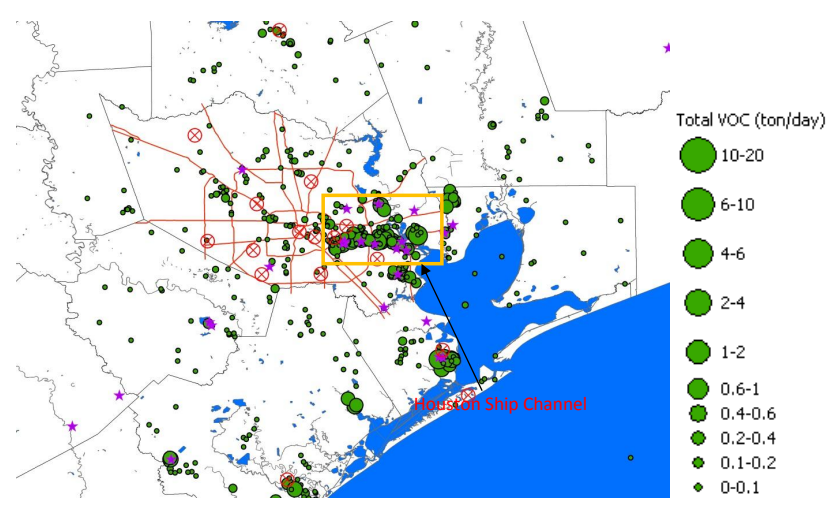

Fig. 1. Map centered on the Houston metropolitan area, showing highways (red lines) and $\mathrm{NO}_{\mathrm{x}}$ and VOC point sources. $\mathrm{NO}_{\mathrm{x}}$ point sources from a continuous emission monitoring system (CEMS) are shown by purple stars. Green circles indicate total VOC emissions rate (tons day ${ }^{-1}$ ) from point sources during TexAQS 2006 (data source: Texas Commission on Environmental Quality). The Houston Ship Channel is identified by a yellow frame. Overall, 17 ground monitors are marked by red-cross-circle.

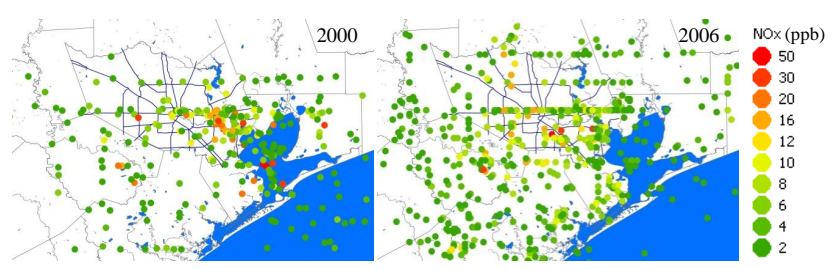

Fig. 2. The spatial distribution of $\mathrm{NO}_{\mathrm{x}}$ concentrations observed by aircraft during TexAQS 2000 and 2006.

The high levels of $\mathrm{C}_{2} \mathrm{H}_{4}$ and $\mathrm{C}_{3} \mathrm{H}_{6}$ interacting with $\mathrm{NO}_{\mathrm{x}}$ have been shown to foster rapid and efficient $\mathrm{O}_{3}$ production in Houston (Kleinman et al., 2002a, 2005; Ryerson et al., 2003; Mao et al., 2010). Previous studies have found that OPR in Houston plumes could exceed $100 \mathrm{ppb} \mathrm{h}^{-1}$ in contrast to around $20-30 \mathrm{ppbh}^{-1}$ in other metropolitan areas (Kleinman et al., 2002a, 2005).

Despite enormous efforts in curbing HRVOC and $\mathrm{NO}_{\mathrm{x}}$ emissions from petrochemical industries and other sources in Houston, peak $8 \mathrm{~h} \mathrm{O}_{3}$ levels have continued to exceed the EPA's $8 \mathrm{~h}$ standard (Cowling et al., 2007; Lefer et al., 2010). Meanwhile, up to recently, no study has assessed how the $\mathrm{O}_{3}$ production and the radical chemistry responded to these emission reductions in the Houston area. Previously, regional transport models were applied to quantify the $\mathrm{O}_{3}$ trends in the eastern US (Gilliland et al., 2008; Zhou et al., 2013). Using these models to investigate the $\mathrm{O}_{3}$ trend in the Houston area is hindered by the significant underestimation of historical emissions of some HRVOCs from petrochemical industries and the complexity of local meteorology, such as landsea breeze and low-level nocturnal jets (Cowling et al., 2007; Parrish et al., 2009).

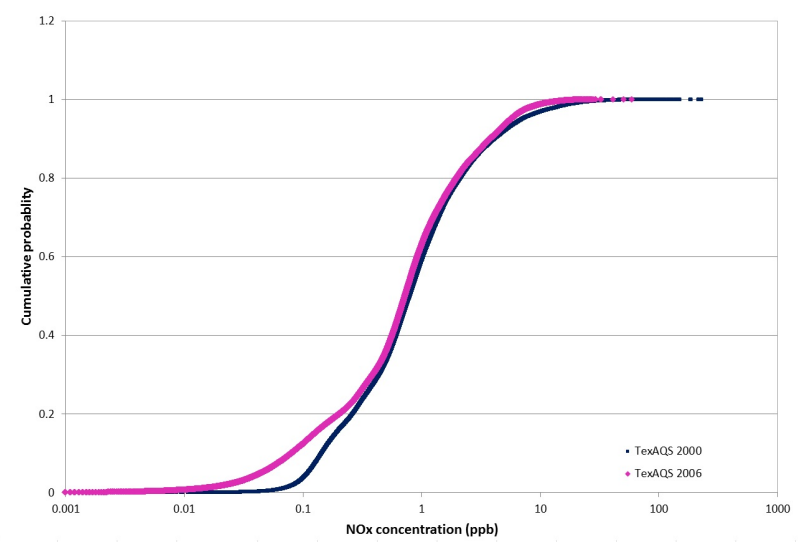

Fig. 3. The cumulative probability distribution of $\mathrm{NO}_{\mathrm{x}}$ concentrations in 2000 and 2006 by using $1 \mathrm{~s} \mathrm{NO}_{\mathrm{x}}$ data from the airborne measurement.

This study averts the shortcomings of the emissions inventories and meteorological simulations by using observationbased analysis and box modeling to explore trends in $\mathrm{O}_{3}$ production in the Houston area. Aircraft-based measurements of Houston pollution plumes during the Texas Air Quality Studies (TexAQS) in 2000 and 2006 provide a comprehensive data source of air pollutant observations over a time gap of 6 years, during which major emission controls occurred in Houston (Cowling et al., 2007; Parrish et al., 2009; Ryerson et al., 2003). An observation-constrained box model coupled with a subset of the Master Chemical Mechanism (Jenkin et al., 2003; Saunders et al., 2003) is applied to compute $\mathrm{HO}_{\mathrm{x}}$ and $\mathrm{RO}_{\mathrm{x}}$ radical concentrations for TexAQS 2000 and 2006.

The second section gives a detailed description of the two TexAQS, the airborne measurement techniques and the metrics of ozone production used in this paper. The third section discusses the changes of measured concentrations, analyzes the changes of the ozone production, and explores the $\mathrm{O}_{3}$ sensitivity to $\mathrm{NO}_{\mathrm{x}}$ and VOC. Finally, we discuss the changes of the ozone production through radical budget analysis, the contributions of $\mathrm{NO}_{\mathrm{x}}$ and VOC to ozone production and how the $\mathrm{O}_{3}$ sensitivity to $\mathrm{NO}_{\mathrm{x}}$ and VOC changes due to the emission controls of both species.

\section{Methodology}

\subsection{Texas Air Quality Studies (TexAQS) 2000 and 2006}

The Texas Air Quality Studies in 2000 and 2006 were designed to investigate sources and atmospheric processes responsible for the formation and transport of photochemical ozone in eastern Texas and the Houston metropolitan area (Figs. 2 and 3) (Cowling et al., 2007; Parrish et al., 2009). The campaigns were conducted from August to September 2000, and September to October 2006. The rapid $\mathrm{O}_{3}$ formation and abundant emissions of HRVOC were identified 


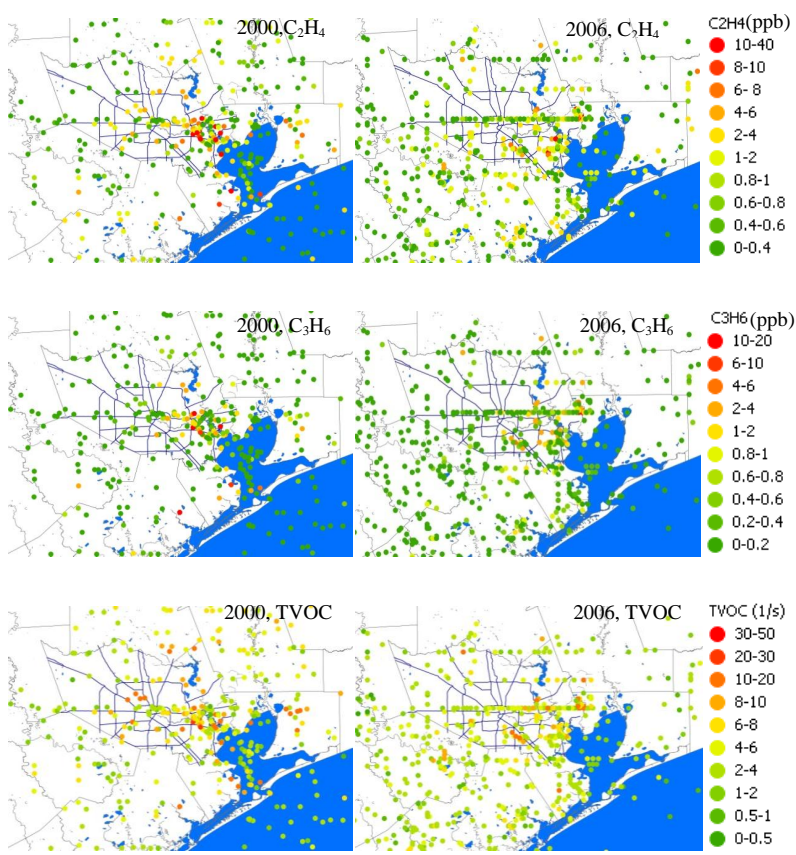

Fig. 4. Spatial distribution of $\mathrm{C}_{2} \mathrm{H}_{4}$ (top), $\mathrm{C}_{3} \mathrm{H}_{6}$ (middle), and total VOC reactivity (TVOC) (bottom) in 2000 and 2006.
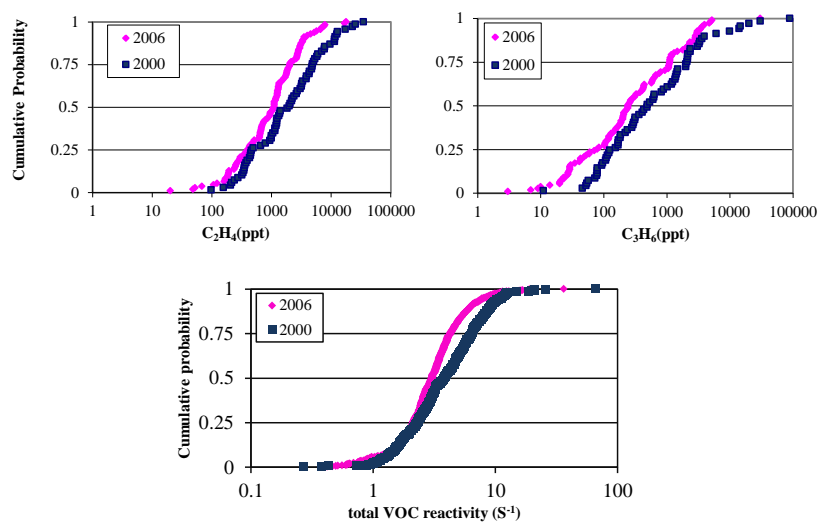

Fig. 5. The cumulative probability distribution of $\mathrm{C}_{2} \mathrm{H}_{4}$ (top left), $\mathrm{C}_{3} \mathrm{H}_{6}$ (top right), and total VOC reactivity (bottom) in 2000 and 2006.

in the plumes from petrochemical facilities during TexAQS 2000 (Figs. 4 and 5) (Daum et al., 2004; Kleinman et al., 2002a; Ryerson et al., 2003).

During TexAQS 2000 and 2006, a full spectrum of chemical species was measured by analytical instruments onboard aircraft. During the two studies, the instruments from NOAA onboard the NCAR aircraft (Electra) in 2000 and the NOAA aircraft (WP-3) in 2006 were applied to measure chemical species over the Houston area for 10 days $(20,23,25,27$, 28, 30 August and 1, 6, 7, and 10 September) in 2000 and for 11 days $(13,15,19,20,21,25,26$, and 27 September; 5,6 , and 10 October) in 2006. The Electra and WP-3 flew at
Table 1. Summary of $\mathrm{O}_{3}(\mathrm{ppb})$ and temperature $\left({ }^{\circ} \mathrm{C}\right)$ during the two campaigns and monthly average for August, September, and October in 2000 and 2006, all data were measured at 17 ground monitors in the Houston metropolitan area (http://www.tceq.state. tx.us/airquality/monops/historical_data.html).

\begin{tabular}{lccccc}
\hline & Year & $\begin{array}{c}\text { Campaign } \\
\text { average }\end{array}$ & August & September & October \\
\hline $\mathrm{O}_{3}$ & 2000 & 76 & 72 & 63 & 51 \\
$(\mathrm{ppb})$ & 2006 & 58 & 52 & 57 & 47 \\
\hline Temperature & 2000 & 34 & 34 & 31 & 26 \\
$\left({ }^{\circ} \mathrm{C}\right)$ & 2006 & 30 & 33 & 30 & 27 \\
\hline
\end{tabular}

heights of 400-700 $\mathrm{m}$ above ground in afternoon hours when sampling pollution plumes, which was well below the typical planetary boundary layer in eastern Texas. A more comprehensive description of the two studies can be found in previous observational studies (Cowling et al., 2007; Parrish et al., 2009; Ryerson et al., 2003).

\subsection{Airborne measurement}

Various instruments onboard the aircraft measured atmospheric compounds with a range of time resolutions. Inorganic species $\left(\mathrm{O}_{3}, \mathrm{H}_{2} \mathrm{O}, \mathrm{NO}_{\mathrm{x}}, \mathrm{HNO}_{3}, \mathrm{SO}_{2}, \mathrm{CO}\right.$, and $\mathrm{CO}_{2}$ ), photolysis rates of chemical species, and meteorological parameters were measured at $1 \mathrm{~s}$ time resolution. In both years, hydrocarbons (e.g., HRVOC, isoprene) and oxygenated VOCs (e.g., HCHO, peroxyacetyl nitrate (PAN)) were measured with different instruments at different time resolutions. $\mathrm{C}_{2}-\mathrm{C}_{10}$ alkanes, $\mathrm{C}_{2}-\mathrm{C}_{5}$ alkenes (including $\mathrm{C}_{2} \mathrm{H}_{4}$ and $\mathrm{C}_{3} \mathrm{H}_{6}$ ), ethyne, and $\mathrm{C}_{2}-\mathrm{C}_{5}$ aldehydes and ketones were measured via whole air samples (WAS) in canisters. Hydrocarbons in WAS were analyzed in laboratories by gas chromatography mass spectrometry (GCMS) for non-methane hydrocarbons (NMHC) $(\mathrm{C} \geq 3)$ and gas chromatography with flame ionization detector (GCFID) for NMHC $\left(\mathrm{C}_{1}-\mathrm{C}_{5}\right)$. There were a total of 726 WAS measurements in 2000 and 814 in 2006.

A total of 37 VOC species were measured in 2000 and 2006 (alkene: 12 species; alkane: 12 species; oxygenated species: 13 species). HCHO was measured using tunable diode absorption spectrometry with $1 \mathrm{~Hz}$ data. Oxygenated VOCs, such as acetic acid, acetone, acetonitrile, methyl ethyl ketone (MEK), methanol, methyl vinyl ketone (MVK) and methacrolein (MACR) were measured by proton transfer reaction mass spectrometry (PTRMS) every $15 \mathrm{~s}$. PAN was measured by chemical ionization mass spectrometry (CIMS). A full description of all chemical species and the corresponding instruments can be found in Table 1a of Parrish et al. (2009).

Four HRVOC species were identified to be critical in the Houston area due to their high concentration and substantial contribution to the local $\mathrm{O}_{3}$ formation. They are $\mathrm{C}_{2} \mathrm{H}_{4}$, 

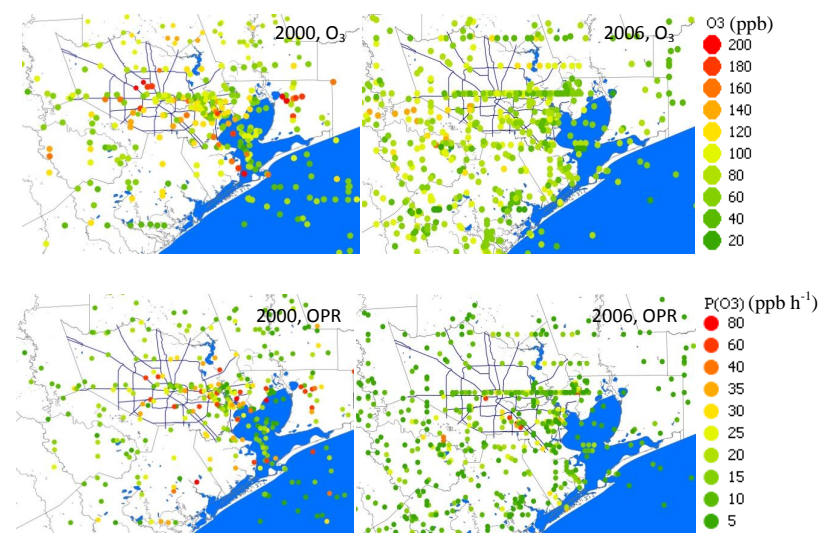

Fig. 6. Spatial distribution of $\mathrm{O}_{3}$ (top) and OPR (bottom) during TexAQS 2000 and 2006.

$\mathrm{C}_{3} \mathrm{H}_{6}$, all butene isomers, and 1,3-butadiene. In particular, $\mathrm{C}_{2} \mathrm{H}_{4}$ and $\mathrm{C}_{3} \mathrm{H}_{6}$ were the two most important species and were suggested to have the largest impact on ozone production in Houston plumes (Ryerson et al., 2003).

Samples were filtered to remove nighttime samples, since $\mathrm{O}_{3}$ production occurs only during daytime, and samples that lacked valid measurements of key species $\left(\mathrm{NO}, \mathrm{NO}_{2}, \mathrm{O}_{3}\right.$, and VOCs). After this processing, there were 472 samples in 2000 and 675 samples in 2006.

Because the airborne samples were essentially discrete, cumulative probability distributions are a good option to compare concentrations between 2000 and 2006. The following analysis will frequently discuss the high (top of $10 \%$ samples, i.e, high OPR means the highest $10 \%$ of samples ranked by OPR), middle (central 20\%), and low (bottom $10 \%)$ samples. For each subset, the mean value of its samples will be compared between 2000 and 2006 .

\subsection{Observation-based box model}

In TexAQS 2000 and 2006, no valid measurements of $\mathrm{HO}_{\mathrm{x}}$ and $\mathrm{RO}_{2}$ were available for computing the ozone production metrics. A box model, the Dynamically Simple Model of Atmospheric Chemical Complexity (DSMACC) (Emmerson and Evans, 2009) based on the kinetic pre-processor (KPP) (Sandu and Sander, 2006), is applied to compute the concentrations of $\mathrm{HO}_{\mathrm{x}}$ and $\mathrm{RO}_{2}$. DSMACC has been applied to simulate radicals in other studies (Henderson et al., 2011, 2012; Stone et al., 2010).

The measured photolysis rates of $\mathrm{NO}_{2}, \mathrm{O}_{3}$ and $\mathrm{HCHO}$ are used to constrain photolysis rates in DSMACC. Meteorological inputs include temperature, pressure, and water mixing ratio. The MCM mechanism used in this study is a subset of the comprehensive MCM v3.2 (http://mcm.leeds.ac.uk/ $\mathrm{MCM} /$ project.htt\#New_3.2) and explicitly represents the 37 VOC species measured in TexAQS 2000 and 2006. It con- tains 3145 chemical reactions, including 3101 organic reactions and 44 inorganic reactions.

The diurnal steady-state approach (Olson et al., 2012) is applied to constrain the long-lived species to measurement. Each input point of in situ data is integrated by the model to find an internally self-consistent diurnal cycle for all computed species to within a given tolerance $(<0.1 \%)$. Predictions are taken from the computed diurnal cycle at the same time of day as the data for direct comparison of radical predictions and measurements.

\subsection{Ozone metrics}

In evaluating the ozone production, four commonly used ozone metrics are applied in this study. They are total $\mathrm{OH}$ reactivity of VOCs (TVOC), ozone production rate (OPR), the fraction of radicals removed by reactions with $\mathrm{NO}_{\mathrm{x}}\left(L_{\mathrm{N}} / Q\right)$, and ozone production efficiency (OPE).

The product of the concentration of a VOC species, and its reaction rate with $\mathrm{OH}$, indicates its potential to form first-generation peroxy radicals that facilitate $\mathrm{O}_{3}$ formation. TVOC is defined in this study as the sum of the $\mathrm{OH}$ reactivity of all VOC species and CO (Eq. 1).

$\mathrm{TVOC}=k_{\mathrm{CO}+\mathrm{OH}}[\mathrm{CO}]+\sum_{i} k_{\mathrm{VOC}_{i}+\mathrm{OH}}\left[\mathrm{VOC}_{i}\right]$

Reactions (R) involved in $\mathrm{O}_{3}$ formation can be grouped into three categories: radical production $(Q)$, chain propagation, and radical termination $(L)$ (Singh, 1995). Radical production paths generate $\mathrm{HO}_{\mathrm{x}}$ and $\mathrm{RO}_{2}$ radical for chain propagation. The three main radical production reactions are (R1)-(R3) $(Q=2 \times \mathrm{R} 1+2 \times \mathrm{R} 2+\mathrm{R} 3)$. The radical losses include radical termination by $\mathrm{NO}_{\mathrm{x}}(\mathrm{R} 4)$ (R7), termed $L_{\mathrm{N}}(=\mathrm{R} 4+\mathrm{R} 5+\mathrm{R} 6-\mathrm{R} 7)$, and radical-radical combinations to form peroxides (R8)-(R11), termed $L_{\mathrm{R}}$ $(=2 \times \mathrm{R} 8+2 \times \mathrm{R} 9+2 \times \mathrm{R} 10+2 \times \mathrm{R} 11)$.

Radical production:

$$
\begin{aligned}
& \mathrm{O}_{3}+h v \rightarrow \mathrm{O}\left({ }^{1} \mathrm{D}\right)+\mathrm{O}_{2} \\
& \mathrm{O}\left({ }^{1} \mathrm{D}\right)+\mathrm{H}_{2} \mathrm{O} \rightarrow 2 \mathrm{OH} \\
& \mathrm{HCHO}+h v \stackrel{\mathrm{O}_{2}}{\longrightarrow} 2 \mathrm{H}_{2} \mathrm{O}+\mathrm{CO} \\
& \text { Alkene }+\mathrm{O}_{3} \rightarrow \gamma \mathrm{RO}_{2}+\cdots
\end{aligned}
$$

Radical loss via $\mathrm{NO}_{\mathrm{x}}$ reactions:

$$
\begin{aligned}
& \mathrm{OH}+\mathrm{NO}_{2} \stackrel{\mathrm{M}}{\longrightarrow} \mathrm{HNO}_{3} \\
& \mathrm{RO}_{2}+\mathrm{NO} \rightarrow \text { organic nitrate } \\
& \mathrm{RCO}_{3}+\mathrm{NO}_{2} \stackrel{\mathrm{M}}{\longrightarrow} \mathrm{RCO}_{3} \mathrm{NO}_{2} \\
& \mathrm{RCO}_{3} \mathrm{NO}_{2} \rightarrow \mathrm{RCO}_{3}+\mathrm{NO}_{2}
\end{aligned}
$$

Radical loss via radical-radical combination:

$$
\begin{aligned}
& \mathrm{HO}_{2}+\mathrm{HO}_{2} \rightarrow \mathrm{H}_{2} \mathrm{O}_{2}+\mathrm{O}_{2} \\
& \mathrm{RO}_{2}+\mathrm{HO}_{2} \rightarrow \mathrm{ROOH}+\mathrm{O}_{2} \\
& \mathrm{OH}+\mathrm{HO}_{2} \rightarrow \mathrm{H}_{2} \mathrm{O}+\mathrm{O}_{2} \\
& \mathrm{RO}_{2}+\mathrm{R}^{\prime} \mathrm{O}_{2} \rightarrow \mathrm{RO}_{2} \mathrm{R}^{\prime} \mathrm{O}_{2}
\end{aligned}
$$


Since $\mathrm{NO}_{2}$ photolysis is the dominant reaction known to form $\mathrm{O}_{3}$ in the troposphere, the ozone production rate is equivalent to the formation rate of $\mathrm{NO}_{2}$ via two production channels: the reaction of $\mathrm{HO}_{2}$ with $\mathrm{NO}$ and the reactions of organic peroxy radical $\left(\mathrm{RO}_{2}\right)$ with $\mathrm{NO}$ (Eq. 2). $\mathrm{NO}_{2}$ is also formed by the reaction of $\mathrm{NO}$ with $\mathrm{O}_{3}$, but this cycling of $\mathrm{NO}_{x}$ yields no net change in $\mathrm{O}_{3}$ during the daytime. The $\mathrm{O}_{3}$ loss paths $\left(\mathrm{L}\left(\mathrm{O}_{3}\right)\right)$ include $\mathrm{O}_{3}$ photolysis to generate $\mathrm{O}\left({ }^{1} \mathrm{D}\right)$ and subsequent formation of $\mathrm{OH}$ radical; the reaction of $\mathrm{O}_{3}$ with $\mathrm{OH}$ and $\mathrm{HO}_{2}$; and the ozonolysis of VOCs (mainly alkenes). Radical loss to aerosol was dominated by $\mathrm{HO}_{2}$ heterogeneous uptake by aerosols. Radical loss to aerosols is unimportant in the Houston urban area where $\mathrm{HO}_{2}$ concentration reached ppt levels; in particular, during the two airborne campaign periods in the afternoon hours, aerosol concentration was typically low, and maximal $\mathrm{HO}_{2}$ was around 50 ppt (Mao et al., 2010). Net_OPR is the difference of OPR and $\mathrm{L}\left(\mathrm{O}_{3}\right)$ (Eq. 5). FR is the fraction of $\mathrm{O}\left({ }^{1} \mathrm{D}\right)$ that generates $\mathrm{OH}$ radical rather than returning to ground-state odd oxygen.

$$
\begin{aligned}
& \mathrm{P}\left(\mathrm{O}_{3}\right)=k_{\mathrm{HO}_{2}+\mathrm{NO}}\left[\mathrm{HO}_{2}\right][\mathrm{NO}] \\
& +\sum_{i} k_{\mathrm{RO}_{2}(i)+\mathrm{NO}}\left[\mathrm{RO}_{2}(i)\right][\mathrm{NO}] \\
& \mathrm{L}\left(\mathrm{O}_{3}\right)=\left\{k_{\mathrm{O}_{3}+\mathrm{R}}[\mathrm{R}]+k_{\mathrm{O}_{3}+\mathrm{HO}_{2}}\left[\mathrm{HO}_{2}\right]\right. \\
& \left.+k_{\mathrm{O}_{3}+\mathrm{OH}}[\mathrm{OH}]+\mathrm{FR} j\left(\mathrm{O}\left({ }^{1} \mathrm{D}\right)\right)\right\}\left[\mathrm{O}_{3}\right] \\
& \mathrm{FR}=\frac{k_{\mathrm{O}\left({ }^{1} \mathrm{D}\right)+\mathrm{H}_{2} \mathrm{O}}\left[\mathrm{H}_{2} \mathrm{O}\right]}{k_{\mathrm{O}\left({ }^{1} \mathrm{D}\right)+\mathrm{H}_{2} \mathrm{O}}\left[\mathrm{H}_{2} \mathrm{O}\right]+k_{\mathrm{O}\left({ }^{1} \mathrm{D}\right)+\mathrm{M}}[\mathrm{M}]} \\
& \text { net_P }\left(\mathrm{O}_{3}\right)=\mathrm{P}\left(\mathrm{O}_{3}\right)-\mathrm{L}\left(\mathrm{O}_{3}\right)
\end{aligned}
$$

In Eq. (2), $k_{\mathrm{HO}_{2}+\mathrm{NO}}$ and $k_{\mathrm{RO}_{2}(i)+\mathrm{NO}}$ are the reaction rate coefficients for reactions of $\mathrm{HO}_{2}$ and $\mathrm{RO}_{2}$ species with NO. The MCM mechanism in this study has $217 \mathrm{RO}_{2}$ species. Since $\mathrm{L}\left(\mathrm{O}_{3}\right)$ was negligible compared to OPR in polluted daytime samples, we focus our attention on OPR rather than net_OPR.

Whether radicals are removed primarily via reactions with $\mathrm{NO}_{\mathrm{x}}\left(L_{\mathrm{N}}\right)$ or with other radicals $\left(L_{\mathrm{R}}\right)$ depends on the relative abundance of $\mathrm{NO}_{\mathrm{x}}$ and radicals. $L_{\mathrm{N}} / Q$ is the fraction of radicals removed via the $\mathrm{NO}_{\mathrm{x}}$ reactions, assuming that radical production and removal are in balance (Kleinman, 2005). This metric indicates whether the $\mathrm{O}_{3}$ formation is $\mathrm{NO}_{\mathrm{x}^{-}}$or VOC-sensitive (Kleinman et al., 1997, 2005). When $L_{\mathrm{N}} / Q$ is less than 0.5, it suggests a low $\mathrm{NO}_{\mathrm{x}}$ regime and $\mathrm{NO}_{\mathrm{x}}-$ sensitive $\mathrm{O}_{3}$ formation, while larger values of $L_{\mathrm{N}} / Q$ indicate a high $\mathrm{NO}_{\mathrm{x}}$, VOC-sensitive regime.

Ozone production efficiency (OPE) describes the number of molecules of $\mathrm{O}_{3}$ generated per molecule of $\mathrm{NO}_{\mathrm{x}}$ oxidized into reactive nitrogen species (e.g., $\mathrm{HNO}_{3}$ and organic nitrate) and can be defined in either of two ways. Accumulative OPE compares aggregate $\mathrm{O}_{3}$ formation and $\mathrm{NO}_{\mathrm{x}}$ loss based on the slope of the least square fit between $\mathrm{O}_{3}$ and $\mathrm{NO}_{\mathrm{z}}$ ( $\equiv \mathrm{NO}_{\mathrm{y}}-\mathrm{NO}_{\mathrm{x}}$, where $\mathrm{NO}_{\mathrm{y}}$ is total reactive nitrogen) observations. Accumulative OPE gives an upper limit of actual OPE because $\mathrm{NO}_{\mathrm{z}}$ loss via deposition is ignored. Instantaneous

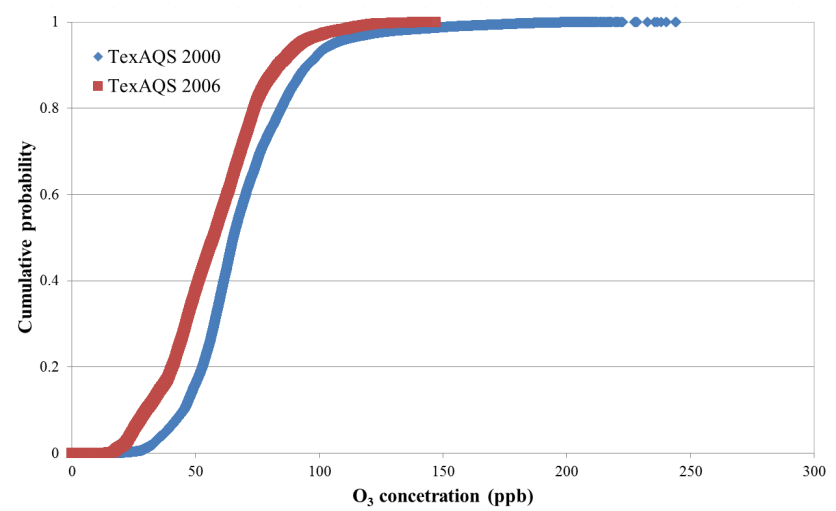

Fig. 7. The cumulative probability distribution of $\mathrm{O}_{3}$ in 2000 and 2006 by using $1 \mathrm{~s} \mathrm{O}_{3}$ data from the airborne measurements.

OPE characterizes current rates of $\mathrm{O}_{3}$ production per $\mathrm{NO}_{\mathrm{x}}$ oxidized based on Eq. (6):

$$
\begin{aligned}
& \mathrm{OPE}=\mathrm{P}\left(\mathrm{O}_{3}\right) / \mathrm{L}\left(\mathrm{NO}_{\mathrm{x}}\right) \\
& \begin{aligned}
\mathrm{L}\left(\mathrm{NO}_{\mathrm{x}}\right) & =k_{\mathrm{OH}+\mathrm{NO}_{2}}[\mathrm{OH}]\left[\mathrm{NO}_{2}\right] \\
& +\sum_{i} k_{\mathrm{NO}+\mathrm{RO}_{2}(i)}[\mathrm{NO}]\left[\mathrm{RO}_{2}(i)\right] \\
& +\sum_{i} k_{\mathrm{NO}_{2}+\mathrm{RCO}_{3}(i)}\left[\mathrm{NO}_{2}\right]\left[\mathrm{RCO}_{3}(i)\right] \\
& -\sum_{i} k_{\mathrm{RCO}_{3} \mathrm{NO}_{2}(i)}\left[\mathrm{RCO}_{3} \mathrm{NO}_{2}(i)\right] .
\end{aligned}
\end{aligned}
$$

\section{Results}

\subsection{Changes of $\mathrm{NO}_{\mathrm{x}}, \mathrm{HRVOC}$, and $\mathrm{O}_{3}$ concentration}

$\mathrm{NO}_{\mathrm{x}}$ and HRVOCs in the Houston area declined by $17 \%$ and $40 \%$, respectively, between the campaigns, which is consistent with previous studies (Cowling et al., 2007; Gilman et al., 2009; Washenfelder et al., 2010). A more detailed discussion of the change of $\mathrm{NO}_{\mathrm{x}}$ and $\mathrm{VOC}$ concentrations in the Houston area could be found in Washenfelder (2010). The cumulative distribution of $\mathrm{O}_{3}$ concentration shows substantial reductions from 2000 to 2006 for high percentile observations, but little change for low percentiles (Fig. 7). This is consistent with Zhou et al. (2013), who found sharper reductions in ozone on peak days than cleaner days in the eastern US.

The daily $\max 8 \mathrm{~h} \mathrm{O}_{3}$ concentration and daily max temperature averaged over all available ground sites in the Houston area are presented in Figs. S1 and S2. There were a total 17 ground monitors that observed $\mathrm{O}_{3}$ and temperature in both 2000 and 2006 (Fig. 1). Monthly $\mathrm{O}_{3}$ concentration in the summer (August, September and October) of 2000 was higher than in 2006 by $4-20 \mathrm{ppb}$ (Table 1). The $\mathrm{O}_{3}$ level in TexAQS 2000 was higher than in TexAQS 2006 by 18 ppb. Monthly average temperature in summer of 2000 was higher than in 2006 by $1^{\circ} \mathrm{C}$. Temperature during TexAQS 2000 was higher than in TexAQS 2006 by $4{ }^{\circ} \mathrm{C}$. The temperature gap 
Table 2. Parameters of $\mathrm{O}_{3}$ production for the high, middle and low OPR samples for 2000 and $2006^{*}$.

\begin{tabular}{lrr|rr|rr}
\hline Parameters & \multicolumn{2}{c|}{ High OPR } & \multicolumn{2}{|c|}{ Middle OPR } & \multicolumn{2}{c}{ Low OPR } \\
& 2000 & 2006 & 2000 & 2006 & 2000 & 2006 \\
\hline $\mathrm{OPR}\left(\mathrm{ppb} \mathrm{h}^{-1}\right)$ & 58.9 & 26.4 & 12.4 & 6.4 & 0.8 & 0.3 \\
$\mathrm{O}_{3}(\mathrm{ppb})$ & 123 & 75 & 80 & 61 & 66 & 57 \\
$\mathrm{Q}\left(\mathrm{ppb} \mathrm{h}^{-1}\right)$ & 12.5 & 6.1 & 2.8 & 2.2 & 1.1 & 0.4 \\
$\mathrm{NO}_{\mathrm{x}}(\mathrm{ppb})$ & 14.1 & 7.2 & 4.6 & 3.2 & 0.3 & 1.0 \\
$\mathrm{TVOC}\left(\mathrm{s}^{-1}\right)$ & 12.0 & 6.7 & 4.2 & 2.8 & 1.9 & 1.7 \\
$L_{\mathrm{N}} / Q$ & 0.8 & 0.9 & 0.5 & 0.7 & 0.2 & 0.2 \\
\hline
\end{tabular}

* All values of parameters are the mean for the subset. The parameters chosen here follow Table 4 of Kleinman et al. (2005). High OPR refers to the top $10 \%$ samples ranked by OPR; middle OPR is the central $20 \%$ samples; and low OPR refers to the bottom $10 \%$ samples.

between TexAQS 2000 and TexAQS 2006 was mostly due to extreme hot days from 29 August to 6 September in 2000. Lower $\mathrm{O}_{3}$ did not entirely result from emissions reductions, as different meteorology, including lower temperatures, also played a role. We acknowledge that changes of $\mathrm{O}_{3}$ levels from 2000 to 2006 were affected by factors beyond emission changes (Draxler et al., 2000). No method could quantify the contributions of these various factors with observational data. The systemical ozone declines observed over a long period (e.g., 1998-2006) from the TCEQ ground monitors could not be simply explained by the meteorological variations but indicate that emission change played a major role (Cowling et al., 2007).

\subsection{Changes of ozone production rate}

This section characterizes the decline in ozone production rate (OPR) between the two campaigns and the roles of $\mathrm{NO}_{\mathrm{x}}$ and VOC emission reductions in these changes. The spatial distribution of OPR in both years indicates that the hotspots of OPR primarily occurred in the HSC and the closely surrounding areas, and declined in frequency from 2000 to 2006 (Fig. 6). The maximal OPR declined $68 \%$ from $209 \mathrm{ppbh}^{-1}$ in 2000 to $66 \mathrm{ppbh}^{-1}$ in 2006 . The maximal OPR in 2000 occurred in the center of the HSC $\left(\mathrm{NO}_{\mathrm{x}}: 29 \mathrm{ppb}\right.$, TVOC: $\left.67 \mathrm{~s}^{-1}\right)$ while the maximal OPR in $2006\left(66 \mathrm{ppb} \mathrm{h}^{-1}\right)$ was observed in the eastern portion of the HSC near Mont Belvieu $\left(\mathrm{NO}_{\mathrm{x}}\right.$ : $8 \mathrm{ppb}$, TVOC: $\left.11 \mathrm{~s}^{-1}\right)$. More broadly, the average of the highest $10 \%$ of OPR declined $55 \%$ from $59 \mathrm{ppb} \mathrm{h}^{-1}$ in 2000 to $26 \mathrm{ppbh}^{-1}$ in 2006 , while the average of the middle $20 \%$ of OPR declined $48 \%$ from $12 \mathrm{ppbh}^{-1}$ to $6 \mathrm{ppbh}^{-1}$ (Table 2).

The dependence of OPR on $\mathrm{NO}_{\mathrm{x}}$ concentration is shown in Fig. 8 for both years. For $\mathrm{NO}_{\mathrm{x}}$ concentration $<0.15 \mathrm{ppb}$, OPR did not show strong response to the change of $\mathrm{NO}_{\mathrm{x}}$ concentration for both years. After that, OPR increases rapidly as $\mathrm{NO}_{\mathrm{x}}$ increases. OPR tends to increase with $\mathrm{NO}_{\mathrm{x}}$ at low $\mathrm{NO}_{\mathrm{x}}$ concentration $\left(\mathrm{NO}_{\mathrm{x}}<10 \mathrm{ppb}\right)$. For both years, the peak OPR appears at $\mathrm{NO}_{\mathrm{x}}$ near $10 \mathrm{ppb}$. Beyond this point, OPR declines by $51 \%$ (2000) and $35 \%$ (2006) with further in-

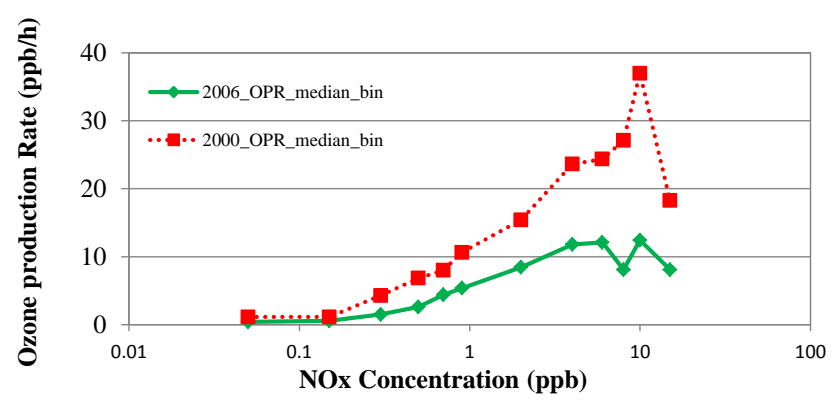

Fig. 8. OPR as a function of $\mathrm{NO}_{\mathrm{x}}$ concentration for 2000 and 2006; measured data is binned by its $\mathrm{NO}_{\mathrm{x}}$ concentration and the median values of OPR for each is shown here.

creases in $\mathrm{NO}_{\mathrm{x}}$, because abundant $\mathrm{NO}_{\mathrm{x}}$ rapidly removes $\mathrm{OH}$ and peroxy radicals. For all $\mathrm{NO}_{\mathrm{x}}$ levels, OPR in 2000 was higher than in 2006, showing a downward shift. The downward shift was very clearly visualized in Fig. 8 for $\mathrm{NO}_{\mathrm{x}}$ concentration $>0.15 \mathrm{ppb}$. The median OPR in 2000 was higher in 2006 by $100-200 \%$ for the same $\mathrm{NO}_{\mathrm{x}}$ concentration at the $\mathrm{NO}_{\mathrm{x}}$ range of $1-15 \mathrm{ppb}$. The downward shift in the data reflects the role of VOC emission reductions.

The dependence of OPR on TVOC and $\mathrm{NO}_{\mathrm{x}}$ concentration in both years is further explored in Fig. 9. There are instances in which high levels of TVOC coincide with high levels of $\mathrm{NO}_{\mathrm{x}}$, indicating collocations of $\mathrm{NO}_{\mathrm{x}}$ and VOC emission sources. The high OPR had high levels of $\mathrm{NO}_{\mathrm{x}}$ and TVOC with the $\mathrm{NO}_{\mathrm{x}} /$ TVOC ratio of around $1: 1 \mathrm{ppb}: 1^{-1}$ for both years (bottom plots of Fig. 9), similar to the results in Lu et al. (2010) and Kleinman et al. (2005). The differences of the OPR between 2000 and 2006 were (1) more instances of extremely high OPR $\left(>70 \mathrm{ppb} \mathrm{h}^{-1}\right)$ in 2000 , reflecting higher TVOC and $\mathrm{NO}_{\mathrm{x}}$; and (2) for the same levels of $\mathrm{NO}_{\mathrm{x}}$ and TVOC $\left(\mathrm{NO}_{\mathrm{x}}<10 \mathrm{ppb}\right.$ and TVOC $\left.<10 \mathrm{~s}^{-1}\right)$, OPR in 2000 tended to be higher than in 2006. For the second difference, one of the reasons is that TVOC does not take account of the fast photolysis of much higher aldehyde and ketone levels in 2000 (e.g., HCHO was 13.9 ppb in 2000 and $7.4 \mathrm{ppb}$ in 2006 for the high OPR). Low OPR was associated with the $\mathrm{NO}_{\mathrm{x}} /$ TVOC ratio of around $1: 10$.

\subsection{Ozone source and radical budget analysis}

Although OPR has been reduced, the relative contribution of VOC sources requires further analysis. This section examines the VOC contributions to OPR by examining radical budgets based on the simulations from the DSMACC model. Average $\mathrm{OH}$ concentrations simulated by DSMACC were similar in each TaxAQS campaign $\left(1.10 \times 10^{7}\right.$ in 2000 and $1.06 \times 10^{7}$ molecules $\mathrm{cm}^{-3}$ in 2006), so $\mathrm{OH}$ trends cannot explain the decline of OPR. The contributions of peroxy radicals to OPR at times of rapid $\mathrm{O}_{3}$ production are summarized in Fig. 10. The $\mathrm{HO}_{2}-\mathrm{NO}$ reaction contributed about 

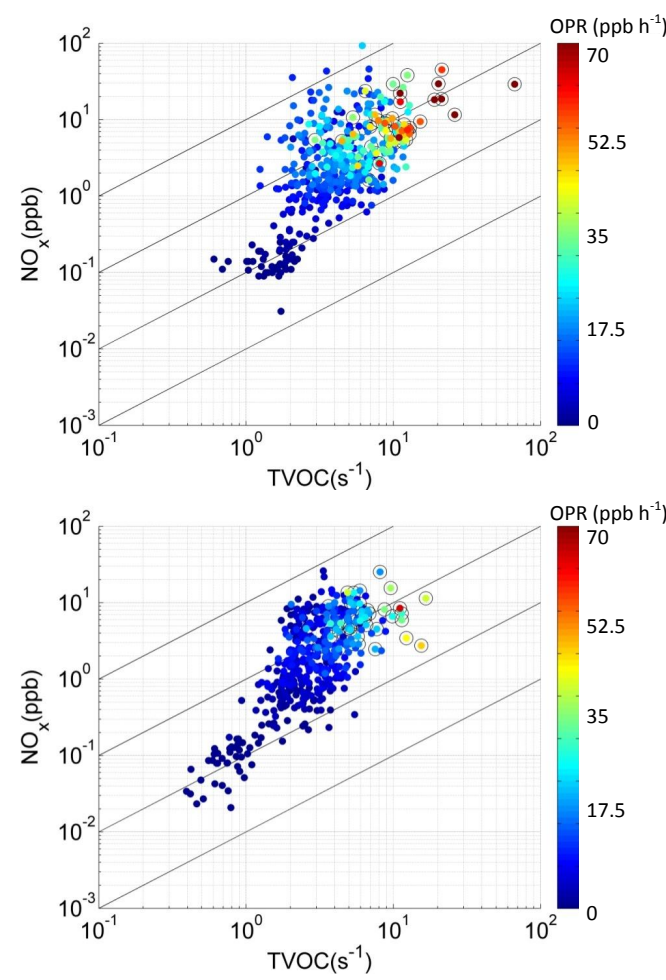

Fig. 9. The dependence of OPR shown in color scale on total VOC reactivity (TVOC) and $\mathrm{NO}_{\mathrm{x}}$ concentration for both 2000 and 2006. In the top plots, samples of high OPR are marked by empty circles. Each diagonal line is associated with a constant TVOC to $\mathrm{NO}_{\mathrm{x}}$ ratio (from top to bottom, TVOC $/ \mathrm{NO}_{\mathrm{x}}=10: 1,1: 1,1: 10,1: 100$ ).

$60 \%$ of the high OPR in both years, though the rate of this reaction plunged significantly (53\%) from 2000 to 2006.

Among the total $217 \mathrm{RO}_{2}$ radicals, 56 species (Table $\mathrm{S} 1$ in the Supplement) which contributed more than $95 \%$ of the OPR from the $\mathrm{RO}_{2}$ and $\mathrm{NO}$ reactions are assigned into five groups: $\mathrm{ALKAO}_{2}, \mathrm{ALKEO}_{2}, \mathrm{CARBO}_{2}, \mathrm{CH}_{3} \mathrm{O}_{2}$, and $\mathrm{ISOPO}_{2}$, approximately reflecting their VOC precursors, i.e., alkanes (C-C), alkenes $(\mathrm{C}=\mathrm{C})$, carbonyls, $\mathrm{CH}_{4}$, and biogenics (Sommariva et al., 2011). Alkenes correspond to HRVOC, while alkanes are mostly anthropogenic saturated hydrocarbons. Carbonyls include a variety of oxygenated VOCs (OVOCs), such as $\mathrm{CH}_{3} \mathrm{CHO}, \mathrm{CH}_{3} \mathrm{COCH}_{3}$, MEK, and MVK, which may be formed from the $\mathrm{OH}$-oxidation of HRVOCs, isoprene and other long-chain hydrocarbons.

Among the $\mathrm{NO}$ and $\mathrm{RO}_{2}$ reactions, the two largest components were $\mathrm{ALKEO}_{2}$ and $\mathrm{CARBO}_{2}$, the combination of which contributed roughly $25 \%$ of the high OPR in both years. $\mathrm{CH}_{3} \mathrm{O}_{2}$ contributed only a small amount $(8.1 \%$ in 2000 and $11.3 \%$ in 2006) to OPR in this study domain, in contrast to the rural atmosphere, where $\mathrm{CH}_{3} \mathrm{O}_{2}$ usually contributes about $30 \%$ of OPR (Sommariva et al., 2011). Alkanes and biogenic VOCs had very small contributions to OPR in the two years.

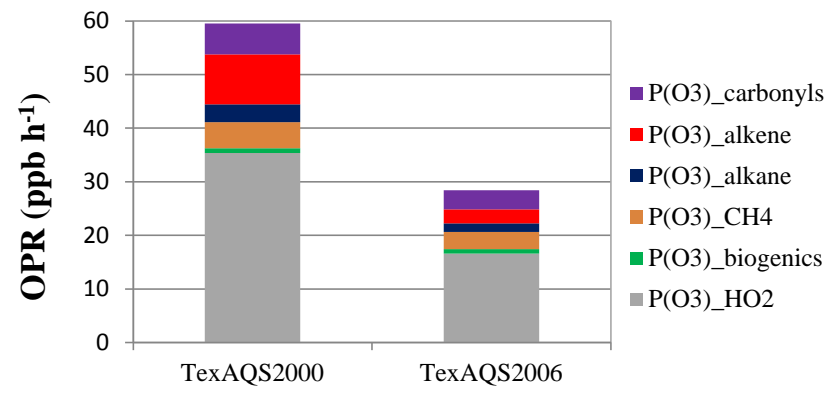

Fig. 10. The contribution of $\mathrm{HO}_{2}$ and $\mathrm{RO}_{2}$ radicals to OPR in the high OPR samples (average: $59 \mathrm{ppb} \mathrm{h}^{-1}$ in 2000 and $26 \mathrm{ppb} \mathrm{h}^{-1}$ in 2006). $\mathrm{RO}_{2}$ radicals are grouped into five categories based on their VOC precursors.

OPR from $\mathrm{RO}_{2}$ radicals of alkanes, carbonyls, and HRVOCs declined dramatically from 2000 to $2006: 53 \%$ for $\mathrm{ALKO}_{2}, 39 \%$ for $\mathrm{CARBO}_{2}$, and $71 \%$ for $\mathrm{ALKEO}_{2}$. Meanwhile, little change was observed from $\mathrm{ISOPO}_{2}$ originating from largely biogenic isoprene, as well as from $\mathrm{CH}_{3} \mathrm{O}_{2}$ originating from long-lived methane, which has numerous biogenic and anthropogenic sources globally. This is consistent with the decline in anthropogenic VOCs and HRVOC between these periods.

From the OPR source analysis, we have seen that the $\mathrm{HO}_{2}$ term was the dominant contributor to the high OPR, and its reduction led to the decline of OPR from 2000 to 2006. The $\mathrm{HO}_{2}$ radical budget for the high OPR samples is examined to investigate sources of $\mathrm{HO}_{2}$ and how they changed over this period. Total $\mathrm{HO}_{2}$ production rate declined by $53 \%$ from $3.77 \times 10^{8} \mathrm{~cm}^{-3} \mathrm{~s}^{-1}$ in 2000 to $1.75 \times 10^{8} \mathrm{~cm}^{-3} \mathrm{~s}^{-1}$ in 2006. Even though $\mathrm{HO}_{2} \mathrm{NO}_{2}$ formation and decomposition has large weights compared to other $\mathrm{HO}_{2}$ loss and production processes (Fig. 11), the net of $\mathrm{HO}_{2} \mathrm{NO}_{2}$ formation and decomposition was only a minor component $(3.4-4.5 \%)$ of the $\mathrm{HO}_{2}$ budget in both years.

Excluding the $\mathrm{HO}_{2} \mathrm{NO}_{2}$ formation and decomposition, $\mathrm{HCHO}+\mathrm{OH}(18 \%), \mathrm{HYPROPO}\left(\mathrm{OHCH}_{2} \mathrm{C}(\mathrm{O} \cdot) \mathrm{CH}_{3}\right)$ photolysis $(14 \%)$, and $\mathrm{HCHO}$ photolysis $(13 \%)$ contributed about half of the $\mathrm{HO}_{2}$ production rate in 2000. In 2006, $\mathrm{HCHO}+\mathrm{OH}(19.1 \%)$, and $\mathrm{HCHO}$ photolysis $(14.0 \%)$ had similar contributions to the $\mathrm{HO}_{2}$ production rate, while the contribution of $\mathrm{HYPROPO}$ to the $\mathrm{HO}_{2}$ production rate declined significantly to $8 \%$.

HYPROPO is predominantly produced from the reaction of $\mathrm{C}_{3} \mathrm{H}_{6}$ with $\mathrm{OH}$ in the MCM. The sources of $\mathrm{HCHO}$ in the Houston area have been substantially debated. A few studies using regression analysis of $\mathrm{HCHO}$ with primary and secondary pollutants have argued that the primary emission has a larger contribution to ground-level HCHO concentrations than secondary formation (Buzcu Guven and Olaguer, 2011; Olaguer et al., 2009; Rappenglück et al., 2010). However, a comprehensive chemical analysis of airborne HCHO coupled with ground $\mathrm{HCHO}$ measurements and emissions data 

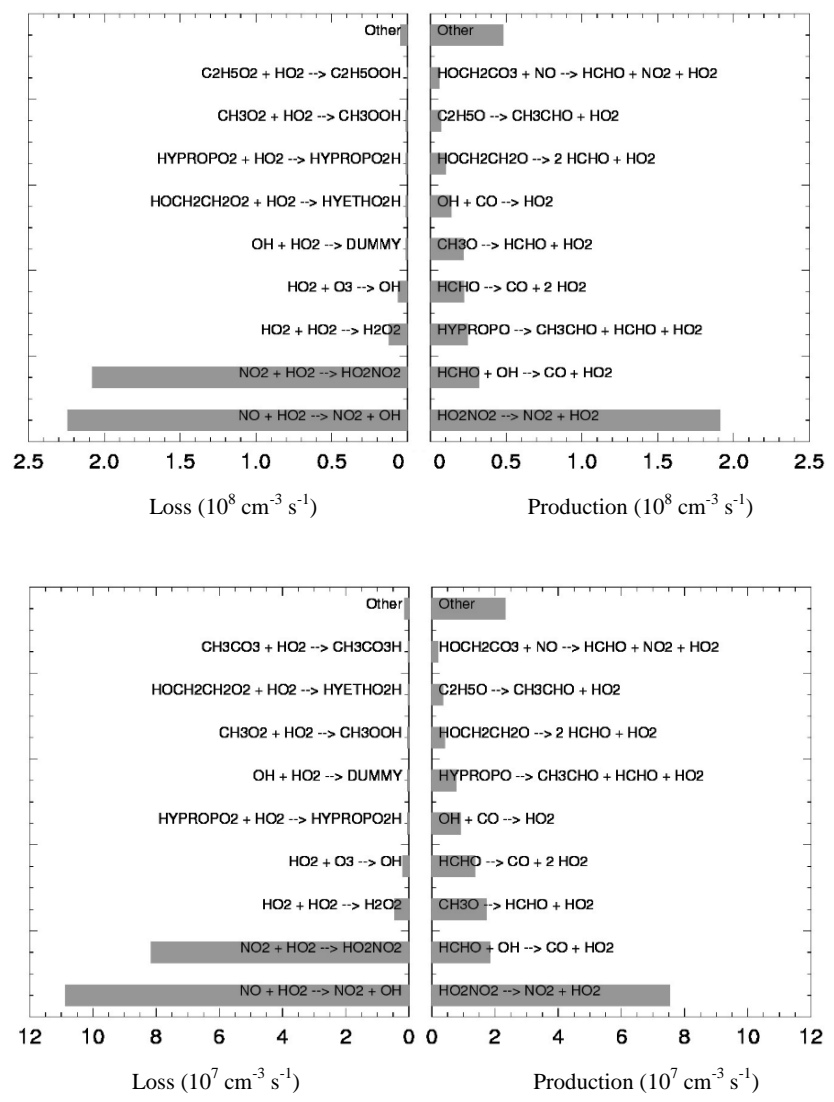

Fig. 11. Loss and production processes of $\mathrm{HO}_{2}$ radical for high OPR samples. Reactions and species are from the MCM.

concluded that HCHO in HGB was predominantly formed from VOC oxidation (Parrish et al., 2012). We used the same airborne data as Parrish et al. (2009). A careful examination of all airborne data in this study did not find HCHO-only spikes, but observed that the enhancements of $\mathrm{HCHO}$ were strongly associated with those of $\mathrm{O}_{3}$. These two facts are consistent with the claim of Parrish et al. (2012) that HCHO primarily (92\%) resulted from HRVOC oxidation. Median and maximal $\mathrm{HCHO}$ declined by $15 \%$ and $21 \%$, respectively, between the 2000 and 2006 campaigns, with the greatest declines at higher percentiles (Fig. S5). Following this assumption, $40 \%$ of $\mathrm{HO}_{2}$ production can be attributed to HRVOC as a conservative estimate in both years.

Other minor contributing reactions include the oxidation of $\mathrm{HOCH}_{2} \mathrm{CH}_{2} \mathrm{O}, \mathrm{C}_{2} \mathrm{H}_{5} \mathrm{O}, \mathrm{HOCH}_{2} \mathrm{CO}_{3}$, and IPROPOLO $\left(\mathrm{OHCH}\left(\mathrm{CH}_{3}\right) \mathrm{CH}_{2}(\mathrm{O} \cdot)\right)$ reactions, contributing a total $15 \%$ of $\mathrm{HO}_{2}$ production rate. These oxygenated intermediate species and radicals could partially be HRVOC oxidation products. Thus, we conclude that HRVOC played a major role in $\mathrm{HO}_{2}$ production in both years, and its emission reduction was key to the decline of $\mathrm{HO}_{2}$ radicals and OPR between the two campaigns.
Aromatics were only minor contributors to the OPR. There were 14 aromatics (benezene, toluene, ethylbenezene, $\mathrm{m} / \mathrm{p}$-xylene, o-xylene, styrene, isoproylbenezene, npropylbenzene, 2-ethytoluene, 3-ethytoluene, 4-ethytoluene, 1,3,5-triemthylbenzene, 1,2,4-trimethylbenzene, and 1,2,3trimethylbenzene) measured by canister during TexAQS 2000 and 2006 (Fig. S6). Among all aromatics, only benzene and toluene contributed $4.5 \%$ of $\mathrm{OH}$ reactivity while others' contribution is negligible due to their substantially lower concentrations and small reaction rate constants.

\section{$3.4 \mathrm{O}_{3}$ sensitivity to $\mathrm{NO}_{\mathrm{x}}$ and TVOC}

Kleinman (1997) introduced an analytic metric, $L_{\mathrm{N}} / Q$, to investigate the relative sensitivity of $\mathrm{O}_{3}$ formation to $\mathrm{NO}_{\mathrm{x}}$ and VOC. This formula has been applied to various urban areas (Kleinman et al., 2005; Lu et al., 2010; Mao et al., 2010). When $L_{\mathrm{N}} / Q$ is less than 0.5 , it suggests a low $\mathrm{NO}_{\mathrm{x}}$ regime and $\mathrm{NO}_{\mathrm{x}}$-sensitive $\mathrm{O}_{3}$ formation, while larger values of $L_{\mathrm{N}} / Q$ indicate a high $\mathrm{NO}_{\mathrm{x}}$, VOC-sensitive regime. Kleinman (2005) evaluated $L_{\mathrm{N}} / Q$ in five major metropolitan areas (i.e., New York, Philadelphia, Houston, Phoenix, and Nashville). In all five metropolitan areas, high OPR occurred under VOC-sensitive formation $\left(0.64<L_{\mathrm{N}} / Q<0.94\right)$ and median OPR occurred under $\mathrm{NO}_{\mathrm{x}}$-sensitive $\mathrm{O}_{3}$ formation $\left(0.12<L_{\mathrm{N}} / Q<0.49\right)$. Mao $(2010)$ reported that $L_{\mathrm{N}} / Q$ computed from TRAMP was between 0.2 and 0.4 .

In both years, the value of $L_{\mathrm{N}} / Q$ spanned a wide range $(0-1)$, suggesting the airborne data represented a wide variety of $\mathrm{O}_{3}$ formation chemistry from places in the immediate vicinity of emission sources in HSC to the background atmosphere (Fig. 12). At low $\mathrm{NO}_{\mathrm{x}}$ levels $(\leq 1 \mathrm{ppb})$ in both years, low $L_{\mathrm{N}} / Q(0-0.5)$ suggested a $\mathrm{NO}_{\mathrm{x}}$-sensitive $\mathrm{O}_{3}$ formation. Higher $L_{\mathrm{N}} / Q(\geq 0.5)$ indicated a VOC-sensitive $\mathrm{O}_{3}$ formation under higher $\mathrm{NO}_{\mathrm{x}}$ levels. The $L_{\mathrm{N}} / Q$ distribution over the $\mathrm{NO}_{\mathrm{x}}-\mathrm{TVOC}$ space presented in this study is similar to the distribution from the G-1 airborne data during TexAQS 2000 (Kleinman et al., 2005). $L_{\mathrm{N}} / Q$ for the high OPR samples $\left(L_{\mathrm{N}} / Q\right.$ in Table 2$)$ was 0.8 and 0.9 , indicating a strongly VOC-sensitive $\mathrm{O}_{3}$ formation regime for 2000 and 2006, while no significant changes of $L_{\mathrm{N}} / Q$ existed between 2000 and 2006, which reflects the simultaneous declines in $\mathrm{NO}_{\mathrm{x}}$ and VOCs.

\subsection{Ozone production efficiency}

The instantaneous OPE computed from the DSMACC box model considers only the chemical processes and not physical ones such as deposition. As indicated in Eq. (6), instantaneous OPE is OPR divided by $\mathrm{L}\left(\mathrm{NO}_{\mathrm{x}}\right) . \mathrm{NO}_{\mathrm{x}}$ loss $\left(\mathrm{L}\left(\mathrm{NO}_{\mathrm{x}}\right)\right)$ is mainly from the reaction of $\mathrm{NO}_{2}$ with $\mathrm{OH}(\mathrm{R} 4)$ and $\mathrm{RCO}_{3}$ (R6)-(R7), and the reaction of $\mathrm{NO}$ with $\mathrm{RO}_{2}$ (R5). The average and maximal instantaneous OPEs were 2.0 and 27, consistent with those in other regions (Griffin et al., 2004; Kleinman et al., 2002b). 

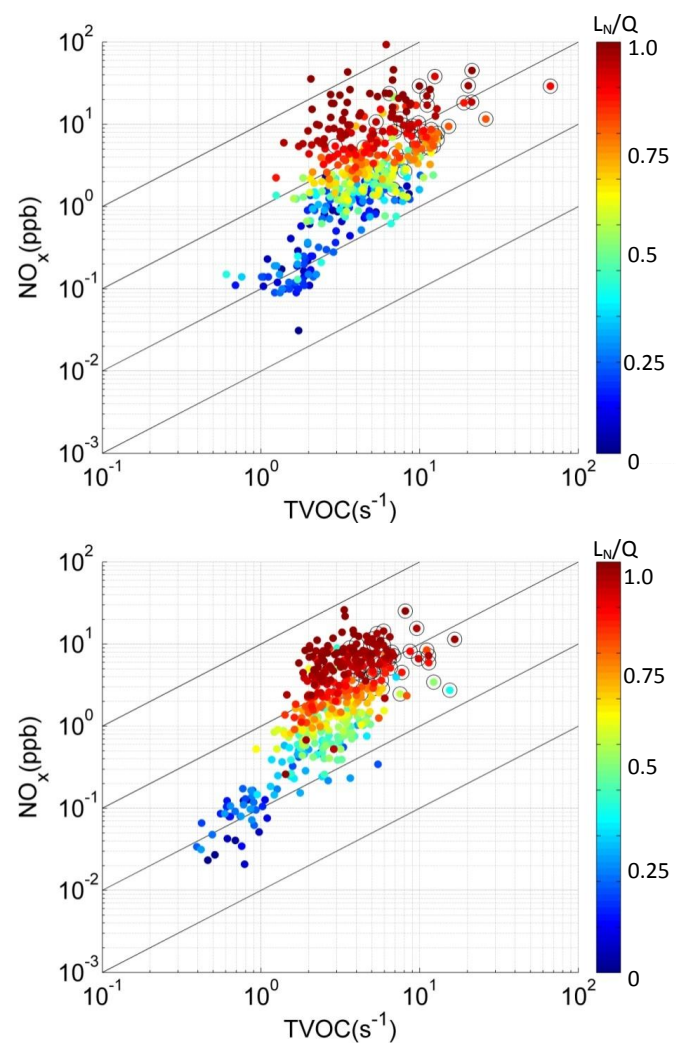

Fig. 12. The dependence of $L_{\mathrm{N}} / Q$ shown in color scale on total VOC reactivity (TVOC) and $\mathrm{NO}_{\mathrm{x}}$ concentration for both 2000 and 2006; samples of high OPR are marked by empty circles. Each diagonal line is associated with a constant TVOC to $\mathrm{NO}_{\mathrm{X}}$ ratio (from top to bottom, TVOC / $\mathrm{NO}_{\mathrm{x}}=10: 1,1: 1,1: 10,1: 100$ ).

While cloud processing could rapidly remove $\mathrm{NO}_{\mathrm{y}}$ in ways not captured by the model and thus lead to overpredictions of OPE (Zhou et al., 2012), MODIS satellite images indicate mostly cloud-free conditions in the immediate vicinity of the transects. Neuman et al. (2009) investigated the correlation between $\mathrm{O}_{3}$ and $\mathrm{NO}_{\mathrm{x}}$ oxidation species from 65 urban and industrial plume transects in the Houston area during TexAQS 2006 and found that OPE was $5.9 \pm 1.2$ (mean \pm standard deviation), among which the highest OPE $(\sim 9)$ was in an isolated petrochemical plume in the Houston Ship Channel. In this work, we found that high OPEs (8-15) were always observed in the diluted industrial plume transects over the isoprene-rich northern rural area, while OPEs in urban and industrial plumes transported southerly tended to be lower (5-7). While both $\mathrm{NO}_{\mathrm{x}}$ and VOCs declined significantly by roughly $17-30 \%$, the accumulative OPEs, derived from the observed $\mathrm{O}_{3}$ and $\mathrm{NO}_{z}$ of $1 \mathrm{~s}$ data samples (e.g., Fig. 13), did not show clear differences between $2000(5.3 \pm 1.1)$ and 2006 ( $4.9 \pm 1.4)$. An example was the closely matched OPEs with the highest $\mathrm{O}_{3}$ between 2000 (5.9-6.7) and 2006 (5.66.4) even though both $\mathrm{O}_{3}$ and $\mathrm{NO}_{z}$ came down substantially (Fig. 13). Specifically, the $1 \mathrm{~s}$ data samples of $\mathrm{O}_{3}$ and $\mathrm{NO}_{\mathrm{z}}$
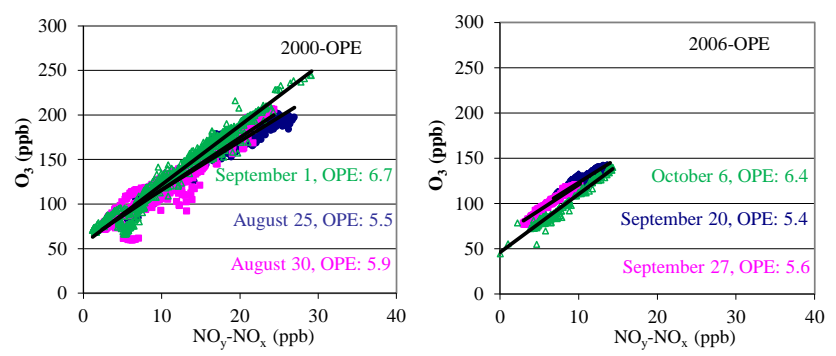

Fig. 13. The accumulative ozone production efficiency (the slope of least square fit between $\mathrm{O}_{3}$ and $\mathrm{NO}_{\mathrm{z}}\left(\mathrm{NO}_{\mathrm{y}}-\mathrm{NO}_{\mathrm{x}}\right)$ concentrations) for the three plumes with the highest $\mathrm{O}_{3}$ in 2000 (left) and 2006 (right).

species from the plumes transects in which the highest $\mathrm{O}_{3}$ concentrations were observed were extracted to plot Fig. 13 . The instantaneous OPE is not directly comparable to the accumulative OPE because the instantaneous OPE involves only chemical reactions and covers a small temporal and spatial subset of data (Griffin et al., 2004).

\section{Discussion and conclusion}

Airborne measurements from TexAQS 2000 and 2006 have been used to investigate the change of ozone production in Houston. A box model, DSMACC, has been applied to simulate $\mathrm{HO}_{\mathrm{x}}$ and $\mathrm{RO}_{2}$ radicals with the airborne data. Total radical concentration, OPR, $L_{\mathrm{N}} / Q$ and OPE are compared between 2000 and 2006 at all levels. A comprehensive summary of the comparison of these parameters is presented in Table 2. The parameters shown in Table 2 for 2000 are consistent with the results from the other airborne measurement (118 samples) by the G-1 aircraft during TexAQS 2000 (Kleinman et al., 2005).

Decreased HRVOC emissions are the main cause of reduced radical production ( $Q$ in Table 2). Total radicals declined about $51 \%$ and $21 \%$ for the high and middle OPR, reflecting the deeper reductions in the most polluted plumes. $\mathrm{HO}_{2}$ and $\mathrm{RO}_{2}$ radicals had similar extents of declines. $\mathrm{RO}_{2}$ sources were dominated by alkenes (HRVOCs) (30-50\%) and carbonyls (30-40\%). $\mathrm{HO}_{2}$ radicals were mainly formed from the HCHO reactions and the HRVOC oxidation products. Our analysis linked the radical decline to the decline in HRVOC emissions. More than $40 \%$ of $\mathrm{HO}_{2}$ production for the high OPR samples could be attributed to HRVOC in both years, and the decline in HRVOCs was critical to the overall decline in radical levels. The simultaneous declines in $\mathrm{NO}_{\mathrm{x}}$ and radicals led to a $40-50 \%$ decline in ozone production rate in the Houston area at times of high and middle OPR (Table 2). OPR declined at all levels of $\mathrm{NO}_{\mathrm{x}}$, reflecting the reduction in VOC levels.

The periods of most rapid ozone production were characterized by VOC-sensitive conditions, as indicated by high 
levels of $L_{\mathrm{N}} / Q$ in samples with high OPR in both years. Meanwhile, the $\mathrm{O}_{3}$ sensitivity for the middle OPR shifted from the transition regime $\left(L_{\mathrm{N}} / Q=0.5\right)$ to the VOCsensitive regime $\left(L_{\mathrm{N}} / Q=0.7\right)$. OPE remained at similarly high levels (5-15) in both years, due to the similar rates of declines in $\mathrm{NO}_{\mathrm{x}}$ and TVOC.

Times of most rapid ozone production in the Houston area were found to be VOC-sensitive (e.g., high OPR in Table 2), and HRVOCs were dominant precursors of peroxy radicals. This suggests the importance of ongoing reductions in HRVOC emissions to achieve further reductions in $\mathrm{O}_{3}$. Nevertheless, $\mathrm{NO}_{\mathrm{x}}$-sensitive conditions continued to be observed at some times and locations (e.g., low OPR in Table 2) and OPE remained high. This study and others (Kleinman et al., 2005; Xiao et al., 2010; Zhang et al., 2004) indicate a need for a balanced approach to emission reductions for a region characterized by co-existence of $\mathrm{NO}_{\mathrm{x}}$ - and VOC-limited formation.

\section{Supplementary material related to this article is available online at http://www.atmos-chem-phys.net/14/ 2777/2014/acp-14-2777-2014-supplement.pdf.}

Acknowledgements. The work of W. Zhou and D. Cohan was funded by National Science Foundation CAREER Award Grant 087386. We thank M. Evans of York University in the UK for providing the DSMACC box model and ropa.pro, a radical budget analysis tool. We thank the NOAA ESRL for providing the TexAQS 2000 and 2006 airborne measurement data. We acknowledge the VOC data from E. Atlas at the National Center for Atmospheric Research (TexAQS 2000) and the University of Miami (TexAQS 2006).

Edited by: B. N. Duncan

\section{References}

Buzcu Guven, B., and Olaguer, E. P.: Ambient formaldehyde source attribution in Houston during TexAQS II and TRAMP, Atmos. Environ., 45, 4272-4280, 2011.

Cowling, E. B., Furiness, C., Dimitriades, B., Parrish, D., and Estes, M.: Final Rapid Science Synthesis Report: Findings from the Second Texas Air Quality Study (TexAQS II), 2007.

Daum, P. H., Kleinman, L. I., Springston, S. R., Nunnermacker, L. J., Lee, Y. N., Weinstein-Lloyd, J., Zheng, J., and Berkowitz, C. M.: Origin and properties of plumes of high ozone observed during the Texas 2000 Air Quality Study (TexAQS 2000), J. Geophys. Res.-Atmos., 109, D17306, doi:10.1029/2003jd004311, 2004.

Draxler, R.: Meteorological factors of ozone predictability at Houston, Texas, J. Air Waste Manage., 50, 259-271, 2000.

Emmerson, K. M. and Evans, M. J.: Comparison of tropospheric gas-phase chemistry schemes for use within global models, At- mos. Chem. Phys., 9, 1831-1845, doi:10.5194/acp-9-1831-2009, 2009.

Gilliland, A. B., Hogrefe, C., Pinder, R. W., Godowitch, J. M., Foley, K. L., and Rao, S. T.: Dynamic evaluation of regional air quality models: Assessing changes in $\mathrm{O}_{3}$ stemming from changes in emissions and meteorology, Atmos. Environ., 42, 5110-5123, 2008.

Gilman, J. B., Kuster, W. C., Goldan, P. D., Herndon, S. C., Zahniser, M. S., Tucker, S. C., Brewer, W. A., Lerner, B. M., Williams, E. J., Harley, R. A., Fehsenfeld, F. C., Warneke, C., and de Gouw, J. A.: Measurements of volatile organic compounds during the 2006 TexAQS/GoMACCS campaign: Industrial influences, regional characteristics, and diurnal dependencies of the $\mathrm{OH}$ reactivity, J. Geophys. Res.-Atmos., 114, D00F06, doi:10.1029/2008jd011525, 2009.

Griffin, R. J., Johnson, C. A., Talbot, R. W., Mao, H., Russo, R. S., Zhou, Y., and Sive, B. C.: Quantification of ozone formation metrics at Thompson Farm during the New England Air Quality Study (NEAQS) 2002, J. Geophys. Res.-Atmos., 109, D24302, doi:10.1029/2004jd005344, 2004.

Haman, C. L., Lefer, B., and Morris, G. A.: Seasonal Variability in the Diurnal Evolution of the Boundary Layer in a NearCoastal Urban Environment, J. Atmos. Ocean. Tech., 29, 697710, doi:10.1175/jtech-d-11-00114.1, 2012.

Henderson, B. H., Pinder, R. W., Crooks, J., Cohen, R. C., Hutzell, W. T., Sarwar, G., Goliff, W. S., Stockwell, W. R., Fahr, A., Mathur, R., Carlton, A. G., and Vizuete, W.: Evaluation of simulated photochemical partitioning of oxidized nitrogen in the upper troposphere, Atmos. Chem. Phys., 11, 275-291, doi:10.5194/acp-11-275-2011, 2011.

Henderson, B. H., Pinder, R. W., Crooks, J., Cohen, R. C., Carlton, A. G., Pye, H. O. T., and Vizuete, W.: Combining Bayesian methods and aircraft observations to constrain the $\mathrm{HO} \cdot+\mathrm{NO}_{2}$ reaction rate, Atmos. Chem. Phys., 12, 653-667, doi:10.5194/acp12-653-2012, 2012.

Jenkin, M. E., Saunders, S. M., Wagner, V., and Pilling, M. J.: Protocol for the development of the Master Chemical Mechanism, MCM v3 (Part B): tropospheric degradation of aromatic volatile organic compounds, Atmos. Chem. Phys., 3, 181-193, doi:10.5194/acp-3-181-2003, 2003.

Kim, S.-W., McKeen, S. A., Frost, G. J., Lee, S.-H., Trainer, M., Richter, A., Angevine, W. M., Atlas, E., Bianco, L., Boersma, K. F., Brioude, J., Burrows, J. P., de Gouw, J., Fried, A., Gleason, J., Hilboll, A., Mellqvist, J., Peischl, J., Richter, D., Rivera, C., Ryerson, T., te Lintel Hekkert, S., Walega, J., Warneke, C., Weibring, P., and Williams, E.: Evaluations of $\mathrm{NO}_{\mathrm{x}}$ and highly reactive VOC emission inventories in Texas and their implications for ozone plume simulations during the Texas Air Quality Study 2006, Atmos. Chem. Phys., 11, 11361-11386, doi:10.5194/acp11-11361-2011, 2011.

Kleinman, L. I.: The dependence of tropospheric ozone production rate on ozone precursors, Atmos. Environ., 39, 575-586, 2005.

Kleinman, L. I., Daum, P. H., Lee, J. H., Lee, Y., Nan, Nunnermacker, L. J., Springston, S. R., Newman, L., Weinstein, Lloyd, J., and Sillman, S.: Dependence of ozone production on NO and hydrocarbons in the troposphere, Geophys. Res. Lett., 24, 22992302, doi:10.1029/97g102279, 1997.

Kleinman, L. I., Daum, P. H., Imre, D., Lee, Y. N., Nunnermacker, L. J., Springston, S. R., Weinstein-Lloyd, J., and Rudolph, J.: 
Ozone production rate and hydrocarbon reactivity in 5 urban areas: A cause of high ozone concentration in Houston, Geophys. Res. Lett., 29, 1467, doi:10.1029/2001g1014569, 2002a.

Kleinman, L. I., Daum, P. H., Lee, Y.-N., Nunnermacker, L. J., Springston, S. R., Weinstein-Lloyd, J., and Rudolph, J.: Ozone production efficiency in an urban area, J. Geophys. Res.-Atmos., 107, 4733, doi:10.1029/2002jd002529, 2002b.

Kleinman, L. I., Daum, P. H., Lee, Y. N., Nunnermacker, L. J., Springston, S. R., Weinstein-Lloyd, J., and Rudolph, J.: A comparative study of ozone production in five U.S. metropolitan areas, J. Geophys. Res.-Atmos., 110, D02301, doi:10.1029/2004jd005096, 2005.

Lefer, B., Rappenglück, B., Flynn, J., and Haman, C.: Photochemical and meteorological relationships during the Texas-II Radical and Aerosol Measurement Project (TRAMP), Atmos. Environ., 44, 4005-4013, 2010.

Lu, K., Zhang, Y., Su, H., Brauers, T., Chou, C., Hofzumahaus, A., Liu, S., Kita, K., Kondo, K., Shao, M., Wahner, A., Wang, J., Wang, X., and Zhu, T.: Oxidant $\left(\mathrm{O}_{3}+\mathrm{NO}_{2}\right)$ production processes and formation in regimes in Beijing, J. Geophys. Res.Atmos., 115, D07303, doi:10.1029/2009JD012714, 2010.

Mao, J., Ren, X., Chen, S., Brune, W. H., Chen, Z., Martinez, M., Harder, H., Lefer, B., Rappenglück, B., Flynn, J., and Leuchner, M.: Atmospheric oxidation capacity in the summer of Houston 2006: Comparison with summer measurements in other metropolitan studies, Atmos. Environ., 44, 4107-4115, 2010.

Neuman, J., Nowak, J., Zheng, W., Flocke, F., Ryerson, T., Trainer, M., Holloway, J., Parrish, D., Frost, G., Peischl, J., Atlas, E., Bahreini, R., Wollny, A., and Fehsenfeld, F.: Relationship between photochemical ozone production and $\mathrm{NO}_{\mathrm{x}}$ oxidation in Houston, Texas, J. Geophys. Res.-Atmos., 114, D00F08, doi:10.1029/2008JD011688, 2009.

Olaguer, E. P., Rappenglück, B., Lefer, B., Stutz, J., Dibb, J., Griffin, R., Brune, W. H., Shauck, M., Buhr, M., Jeffries, H., Wiuete, W., and Pinto, J. P.: Deciphering the Role of Radical Precursors during the Second Texas Air Quality Study, J. Air Waste Manage., 59, 1258-1277, doi:10.3155/1047-3289.59.11.1258, 2009.

Olson, J. R., Crawford, J. H., Brune, W., Mao, J., Ren, X., Fried, A., Anderson, B., Apel, E., Beaver, M., Blake, D., Chen, G., Crounse, J., Dibb, J., Diskin, G., Hall, S. R., Huey, L. G., Knapp, D., Richter, D., Riemer, D., Clair, J. St., Ullmann, K., Walega, J., Weibring, P., Weinheimer, A., Wennberg, P., and Wisthaler, A.: An analysis of fast photochemistry over high northern latitudes during spring and summer using in-situ observations from ARCTAS and TOPSE, Atmos. Chem. Phys., 12, 6799-6825, doi:10.5194/acp-12-6799-2012, 2012.

Parrish, D. D., Allen, D. T., Bates, T. S., Estes, M., Fehsenfeld, F. C., Feingold, G., Ferrare, R., Hardesty, R. M., Meagher, J. F., Nielsen-Gammon, J. W., Pierce, R. B., Ryerson, T. B., Seinfeld, J. H., and Williams, E. J.: Overview of the Second Texas Air Quality Study (TexAQS II) and the Gulf of Mexico Atmospheric Composition and Climate Study (GoMACCS), J. Geophys. Res.Atmos., 114, D00F13, doi:10.1029/2009jd011842, 2009.

Parrish, D. D., Ryerson, T. B., Mellqvist, J., Johansson, J., Fried, A., Richter, D., Walega, J. G., Washenfelder, R. A., de Gouw, J. A., Peischl, J., Aikin, K. C., McKeen, S. A., Frost, G. J., Fehsenfeld, F. C., and Herndon, S. C.: Primary and secondary sources of formaldehyde in urban atmospheres: Houston Texas region,
Atmos. Chem. Phys., 12, 3273-3288, doi:10.5194/acp-12-32732012, 2012.

Rappenglück, B., Dasgupta, P. K., Leuchner, M., Li, Q., and Luke, W.: Formaldehyde and its relation to $\mathrm{CO}, \mathrm{PAN}$, and $\mathrm{SO}_{2}$ in the Houston-Galveston airshed, Atmos. Chem. Phys., 10, 2413 2424, doi:10.5194/acp-10-2413-2010, 2010.

Ryerson, T. B., Trainer, M., Angevine, W. M., Brock, C. A., Dissly, R. W., Fehsenfeld, F. C., Frost, G. J., Goldan, P. D., Holloway, J. S., Hübler, G., Jakoubek, R. O., Kuster, W. C., Neuman, J. A., Nicks, D. K., Jr., Parrish, D. D., Roberts, J. M., Sueper, D. T., Atlas, E. L., Donnelly, S. G., Flocke, F., Fried, A., Potter, W. T., Schauffler, S., Stroud, V., Weinheimer, A. J., Wert, B. P., Wiedinmyer, C., Alvarez, R. J., Banta, R. M., Darby, L. S., and Senff, C. J.: Effect of petrochemical industrial emissions of reactive alkenes and $\mathrm{NO}_{\mathrm{x}}$ on tropospheric ozone formation in Houston, Texas, J. Geophys. Res.-Atmos., 108, 4249, doi:10.1029/2002jd003070, 2003.

Sandu, A. and Sander, R.: Technical note: Simulating chemical systems in Fortran90 and Matlab with the Kinetic PreProcessor KPP-2.1, Atmos. Chem. Phys., 6, 187-195, doi:10.5194/acp-6187-2006, 2006.

Saunders, S. M., Jenkin, M. E., Derwent, R. G., and Pilling, M. J.: Protocol for the development of the Master Chemical Mechanism, MCM v3 (Part A): tropospheric degradation of nonaromatic volatile organic compounds, Atmos. Chem. Phys., 3, 161-180, doi:10.5194/acp-3-161-2003, 2003.

Sommariva, R., Bates, T., Bon, D., Brookes, D., Gouw, J., Gilman, J., Herndon, S., Kuster, W., Lerner, B., Monks, P., Osthoff, H., Parker, A., Roberts, J., Tucker, S., Warneke, C., Williams, E., Zahniser, M., and Brown, S.: Modelled and measured concentrations of peroxy radicals and nitrate radical in the U.S. Gulf Coast region during TexAQS 2006, J. Atmos. Chem., 68, 331362, doi:10.1007/s10874-012-9224-7, 2011.

Singh, H. B.: Composition, Chemistry, and Climate of the Atmosphere, 1 Edn., Wiley, 1995.

Stone, D., Evans, M. J., Commane, R., Ingham, T., Floquet, C. F. A., McQuaid, J. B., Brookes, D. M., Monks, P. S., Purvis, R., Hamilton, J. F., Hopkins, J., Lee, J., Lewis, A. C., Stewart, D., Murphy, J. G., Mills, G., Oram, D., Reeves, C. E., and Heard, D. E.: $\mathrm{HO}_{\mathrm{x}}$ observations over West Africa during AMMA: impact of isoprene and $\mathrm{NO}_{\mathrm{x}}$, Atmos. Chem. Phys., 10, 9415-9429, doi:10.5194/acp-10-9415-2010, 2010.

TCEQ: 2006 TEXAQS/GoMACCS Comprehensive Meteorological Analysis of TexAQS II data, 2007.

Washenfelder, R. A., Trainer, M., Frost, G. J., Ryerson, T. B., Atlas, E. L., de Gouw, J. A., Flocke, F. M., Fried, A., Holloway, J. S., Parrish, D. D., Peischl, J., Richter, D., Schauffler, S. M., Walega, J. G., Warneke, C., Weibring, P., and Zheng, W.: Characterization of $\mathrm{NO}_{\mathrm{x}}, \mathrm{SO} 2$, ethene, and propene from industrial emission sources in Houston, Texas, J. Geophys. Res.-Atmos., 115, D16311, doi:10.1029/2009jd013645, 2010.

Xiao, X., Cohan, D. S., Byun, D. W., and Ngan, F.: Highly nonlinear ozone formation in the Houston region and implications for emission controls, J. Geophys. Res.-Atmos., 115, D23309, doi:10.1029/2010jd014435, 2010.

Zhou, W., Cohan, D. S., Pinder, R. W., Neuman, J. A., Holloway, J. S., Peischl, J., Ryerson, T. B., Nowak, J. B., Flocke, F., and Zheng, W. G.: Observation and modeling of the evolution of 
Texas power plant plumes, Atmos. Chem. Phys., 12, 455-468, doi:10.5194/acp-12-455-2012, 2012.
Zhou, W., Cohan, D. S., and Napelenok, S. L.: Reconciling $\mathrm{NO}_{\mathrm{x}}$ emissions reductions and ozone trends in the U.S., 2002-2006, Atmos. Environ., 70, 236-244, 2013. 